\title{
PEMBELAJARAN BAHASA ARAB SEBAGAI DASAR PENGEMBANGAN KETERAMPILAN MEMBACA KITAB
}

\author{
Asmuki $^{1}$, Ahmadi Muhammadiyah ${ }^{2}$ \\ ${ }^{1,2}$ Universitas Ibrahimy Situbondo \\ 1asmuki@ibrahimy.ac.id, ${ }^{2}$ ahmadi.unib@gmail.com
}

\begin{abstract}
Arabic in its implications in the world of Islamic religious education, especially in Islamic sciences, has a urgent role. As the language of instruction for various references in the rapidly developing branches of science in the global era, Arabic cannot be excluded, although its existence does not exceed English as the language of international communication. It is to enter the doors of Islamic knowledge that Arabic is an important and to be important role to be learned from various branches of linguistics. Both grammatical and various Arabic language skills. For this reason, in every Madrasah, pesantren, and some schools, Arabic language is required to be included in their curriculum.
\end{abstract}

Keywords: Arabic Learning, Development of Reading Skills, Kitab Reading Skills

\section{PENDAHULUAN}

Bahasa Arab di Indonesia mempunyai posisi strategis dalam kajian Islam karena sumber utama ajaran Islam (Alquran dan asSunnah) dan mayoritas referensi ilmu keislaman itu berbahasa Arab. Bahasa Arab di Indonesia mejadi prospek. Karena lembaga pendidikan islam di Indonesia kian berkembang, terutama pondok pesantren di Indonesia sebagai lembaga pendidikan tertua dan perkembangannya yang dinamis mengikuti perubahan zaman. Pondok pesantren, merupakan lembaga pendidikan islam yang berperan dalam mengembangkan dan melesterikan ajaran silam di Indonesia. Pondok pesantren sebagai pusat pendidikan dan pengembangan ilmu keislaman, menggunakan sumber-sumber ilmu dengan literature Arab.

Kurikulum yang digunakan di pondok pesantren berbeda dengan kurikulum yang digunakan di lembaga pendidikan formal yang sudah diatur oleh undang-undang dan memiliki standar khusus lembaga pendidikan di Indonesia. Kurikulum yang digunakan di pondok pesantren menggunakan kurikulum yang ditentukan oleh kiai/ ustadz yang memimpin atau mengasuh pondok pesantren tersebut. Dan standar umum yang menjadi dasar kompetensi pondok pesantren kebanyakan di Indonesia, adalah membaca kitab (buku-buku berbahasa Arab). Membaca kitab memiliki teknis dasar khusus, termasuk materi dan metode pembelajaran yang menyesuaikan kebutuhan dengan tingkat kemampuan peserta didik.

Pada dasarnya, teknik dasar membaca kitab adalah sama di setiap pesantren. Karena memiliki dasar pijakan yang sama, yaitu alQur'an dan beberapa kitab-kitab klasik yang disusun oleh para ulama salaf yang membidanginya secara khusus. Kemudian didesain menjadi sesuai kebutuhan kurikulum pondok pesantren yang hendak menggunakannya, dalam bentuk silabus dengan materi-materi gramatikal maupun materi aplikatif dalam pengembangan keterampilan membaca kitab.

\section{PEMBAHASAN}

Penyusunan atau pengembangan silabus Bimbingan Membaca Kitab memiliki relevansi dengan teori pembelajaran bahasa, terutama pada aspek qira'ah atau reading dan gramatika. Utamanya, bila teori bahasa dikaitkan dengan sistematisasi ulasan materi pembelajaran. Maka dari itu, teori yang akan dibangun dalam artikel ini adalah teori bahasa, terutama bahasa Arab. 


\section{a. Kata dan Makna}

1. Klasifikasi Kata

Kata dalam bahasa Arab disebut al-kalimah. ${ }^{1}$ Al-kalimah menurut salah satu arti leksikalnyabersinonem dengan lafazh. ${ }^{2}$ Sedangkan secara istilah, al-kalimah adalah lafazh yang tersusun dari beberapa huruf hija'iyah yang menunjukkan atas makna terntentu. ${ }^{3}$ Dengan demikian, al-kalimah sama dengan kata dalam bahasa Indonesia.

Dalam bahasa Indonesia, susunan huruf abjad yang mengandung arti itu adalah kata; ada yang disebut kata benda (nomina), kata kerja (verba), kata sifat (adjektiva), kata bilangan (numeralia), kata depan (preposisi), ${ }^{4}$ kata keterangan, kata ganti, dan kata sandang. 5

a) Kata Benda (Nomina), yaitu setiap kata yang pada umumnya menduduki fungsi sebagai subjek, objek, dan pelengkap dalam klausa; berpenanda bentuk -an, ke-... -an, per-...-an, dan sebagainya. Contohnya seperti amalan, kerajaan, perbintangan, dan sebagainya. ${ }^{6}$

b) Kata Kerja (Verba), yaitu kata yang pada umumnya menyandang fungsi predikat, didahului unsur

${ }^{1}$ Afifuddin Muhajir, al-Luqmah al-Saighah $f i$ al-Risalah al-Nahwiyyah, (Situbondo: PP. Salafiyah Syafi'iyah Sukorejo, 2013), h. 6.

2 Sebenarnya, "Kalimat" secara Bahasa memiliki banyak arti. Namun, di sini, hanya disebutkan satu saja, karena modul ini ditujukan bagi pelajar pemula. Keterangan ini dikutip dari: Ibnu Manzhur alAnshari, Lisan al-Arab, Beirut: Dar Shadir, Juz XII, h. 523.

3 Ibnu Manzhur al-Anshari, Lisan al-Arab, Beirut: Dar Shadir, Juz XII, h. 524; dan 'Abbas Hasan, al-Nahwu al-Wafi, Dar al-Ma’arif, Juz I, h. 15.

${ }^{4}$ E. Zainal Arifin dan S. Amran Tasai, Cermat Berbahasa Indonesia untuk Perguruan Tinggi, (Jakarta: Akademika Presindo, 2010), cet. XII, h. 70.

${ }^{5}$ S. Effendi, et.al., Tata Bahasa Dasar Bahasa Indonesia, (Bandung: Remaja Rosdakarya, 2015), cet. I, h. 49, 107, 135, 161, 177, dan 193.

${ }^{6}$ S. Effendi, et.al., Tata Bahasa Dasar Bahasa Indonesia, h. 107. yang berfungsi sebagai subjek dan diikuti oleh objek atau pelengkap; dapat didahului kata seperti sedang, sudah, tidak; mengungkapkan makna tindakan; dan sebagainya. Contohnya yaitu pergi, berdiri, mendengar, ditemukan, dan sebagainya. ${ }^{7}$

c) Kata Sifat (Adjektiva) yaitu kata yang dapat didahului kata penanda tingkat perbandingan lebih atau paling seperti lebih panjang atau paling tinggi, didahului kata penanda taraf sangat atau sekali seperti sangat cantik atau tampan sekali, diakhiri $-\mathrm{i},-\mathrm{iah}$, atau -wi seperti alami, ilmiah, dan duniawi. ${ }^{8}$

d) Kata Bilangan (Numeralia), yaitu kata yang pada umumnya membawa makna 'jumlah atau kuantitas', digunakan untuk menjawab pertanyaan seperti: berapa? keberapa? dan seberapa? Contohnya adalah tiga ekor, lima kilo, lima puluh watt, pertama, dan sebagainya. ${ }^{9}$

e) Kata Depan (Preposisi), yaitu kata yang berada di depan kata/frasa benda, kata/frasa sifat, kata/frasa kerja, kata/frasa ganti, kata bilangan sebagai pelengkapnya atau porosnya dan menunjukkan hubungan tempat, waktu, cara, sarana, dan maksud, dengan kata leksikal lain yang mendahuluinya. Misalnya, mereka tinggal $d i$ Jakatra (hubungan tempat), kami pindah rumah pada hari ini (hubungan waktu), hasil buminya diangkut dengan truk (hubungan sarana), perselisihan diselesaikan secara damai (hubungan cara), dan

\footnotetext{
Indonesia, h. 50.

${ }^{8}$ Akhiran -i, iah, dan wi tertentu pada kata serapan dari bahasa asing. S. Effendi, et.al., Tata Bahasa Dasar Bahasa Indonesia, h. 135-136.

${ }^{9}$ S. Effendi, et.al., Tata Bahasa Dasar Bahasa Indonesia, h. 185-186.
}

${ }^{7}$ S. Effendi, et.al., Tata Bahasa Dasar Bahasa 
contoh dia membuat rumah untuk ibunya (hubungan maksud). ${ }^{10}$

f) Kata Keterangan (Adverbia) merupakan kata yang tumpang tindih dengan kata sifat, seperti baik dapat menjadi contoh kata sifat dan kata keterangan. Karena itulah, tidak mudah menentukan dua kelas kata tersebut (sifat dan keterangan). Perlu ditegaskan di sini, bahwa kata-kata yang mengacu pada waktu seperti besok, dahulu, dulu, esok, kemarin, kini, lampau, lusa, malam, pagi, petang, siang, sore, dan tadi, bukanlah kata keterangan seperti dinyatakan dalam tata bahasa terdahulu, tetapi itu semua adalah kata benda. ${ }^{11}$

g) Kata Ganti, yaitu kata yang digunakan untuk menggantikan kata benda atau perluasannya, atau mengacu kepada seseorang atau sekelompok orang. Misalnya, saya mengenal orang-orang itu. Mereka pegawai depdiknas. ${ }^{12}$

h) Kata Sandang seperti kata Sang, $S i$, dan Para yang ditambahkan diawal kata benda atau kata sifat. ${ }^{13}$

Dalam bahasa Arab, kata (alkalimah) diklasifikasi menjadi tiga yaitu:

a) Kata Benda

Dalam bahasa Arab, kata benda disebut dengan isim (الإسم).

Kata beda atau isim adalah kata yang menunjuk pada benda, barang, hewan, manusia, dan segala yang ada yang tidak memiliki waktu $^{14}$ yang tiga (telah/past, sedang/continous, atau

10 S. Effendi, et.al., Tata Bahasa Dasar Bahasa Indonesia, h. 194.

11 S. Effendi, et.al., Tata Bahasa Dasar Bahasa Indonesia, h. 161-163.

12 S. Effendi, et.al., Tata Bahasa Dasar Bahasa Indonesia, h. 177-178.

13 S. Effendi, et.al., Tata Bahasa Dasar Bahasa Indonesia, h. 191.

${ }^{14}$ Raji al-Asmar, al-Mu'jam al-Mufasshal fi 'Ilmi al-Sharfi, (Beirut: Dar al-Kutub al-Ilmiyah, 2009), h. 80. akan/future). ${ }^{15}$ Contohnya adalah دَفْترِ (buku tulis), كِتَّاب (kitab/buku bacaan), هِرَّة (kucing), dan فَائزّ (Faiz, nama orang).

Ketika kita mendengar kata دَفْترِ (buku tulis), tidak timbul pertanyaan kapan waktunya (buku tulis), apakah akan buku tulis, sedang buku tulis, atau telah buku tulis? Tiga waktu ini tidak bisa bersanding dengan kata "buku tulis" dan semacamnya, karena (buku tulis) tidak mungkin diberi waktu. Itulah maksud dari Kalimat Isim tidak memiliki waktu yang tiga (telah/past, sedang/continous, atau akan/future).

b) Kata Kerja

Kalimat Fi'il dalam Bahasa Indonesia sama dengan kata kerja. Kalimat Fi'il adalah kalimat yang menunjuk pada arti pekerjaan/perbuatan yang terjadi pada salah satu waktu yang tiga:

1) Waktu lampau (past), bermakna "telah," seperti (telah mengetahui) pada

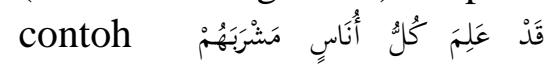
(Sungguh setiap manusia telah mengetahui tempat minumnya).

2) Waktu sekarang (continuous), bermakna "sedang," seperti يَعْلَم

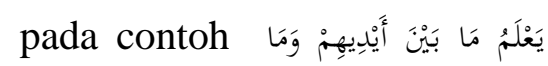
خَخْفَهُ (Allah sedang mengetahui apa saja yang ada di hadapan mereka dan yang ada di belakangnya).

3) Waktu mendatang (future), bermakna akan/bakal, seperti

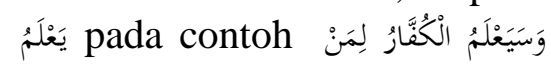
عُعْنَ المَّارِ

15 Abu Bakr Muhammad bin al-Sirri Ibnu Siraj, al-Ushul fi al-Nahwi, (Beirut: Mu'assasah alRisalah, tt.), h. 36-37. 
mengetahui bagi siapakah daerah balasan/surga). ${ }^{16}$

c) Kata Huruf

$$
\text { Huruf dalam Bahasa }
$$
Indonesia sama dengan kata penghubung yang menghubungkan antar satu kata dengan kata lain. ${ }^{17}$ Huruf tidak dapat dipaham kecuali bersanding dengan kalimat lain, misalnya tiba-tiba ada orang mengatakan في (di), (dari), إِلَّ(ke), dan sebagainya. Siapa pun yang mendengarnya pasti bertanya-tanya apa maksudnya.

Kata في إلَّن dan sebagainya baru dapat dimengerti maksudnya bila kata tersebut disambung dengan kata benda. ${ }^{18}$ seperti أُصَلِّي الْعَصْرَ فِن الْمَسْنِجِدِ جَمَاعَة (Aku melakukan shalat berjamaah Ashar di masjid), أَرْجِعُ مِنَ الْمَسْجِدِ بَعْدَ تَعْلِيْمِ الْلِتَابِ (Aku turun dari masjid setelah pengajian kitab), أَذْهَبُ إلَلى المِذْرَسَة بَعْد صَلاَةٍٍ الضُحَى (Aku pergi ke sekolah setelah melaksanakan shalat Dluha).

\section{Klasifikasi Jenis Kata}

Setelah dipaparkan mengenai klasifikasi kata, berikut ini akan dijabarkan klasifikasi jenis kata benda, jenis kata kerja, dan jenis kata huruf. Dipandang dari segi klasifikasi kata menurut Bahasa Indonesia, maka kata dalam Bahasa Arab delapan kelas jenis kata dalam Bahasa Indonesia dapat disederhanakan menjadi tiga jenis kata dalam Bahasa Arab, yaitu:

a. Jenis Kata Benda (Isim), meliputi kelas kata benda (nomina) itu sendiri, kelas kata sifat (adjektiva), kelas kata bilangan (numeralia),

${ }^{16}$ Abu al-Hasan Ali bin Hisyam al-Kailani, Syarh Kailani Izzi, (Indonesia: Maktabah Dar al-Kutub al-Arabiyah), h. 1.

17 Ahmad bin Muhammad al-Andalusy, alHudud fi 'Ilmi al-Nahwi, (Madinah: al-Jami'ah alIslamiyyah, 2001), h. 436.

${ }_{18}$ Abu Bakr Muhammad bin al-Sirri Ibnu Siraj, al-Ushul fi al-Nahwi, (Beirut: Mu'assasah alRisalah, tt.), h. 41. kelas kata kata ganti, dan kelas kata sandang.

b. Jenis Kata Kerja (Fi'il), yaitu kelas kata kerja itu sendiri.

c. Jenis Kata Huruf, yaitu kelas kata depan.

Table 2.1

Skema Jenis Kata

Perpspektif Bahasa

Indonesia

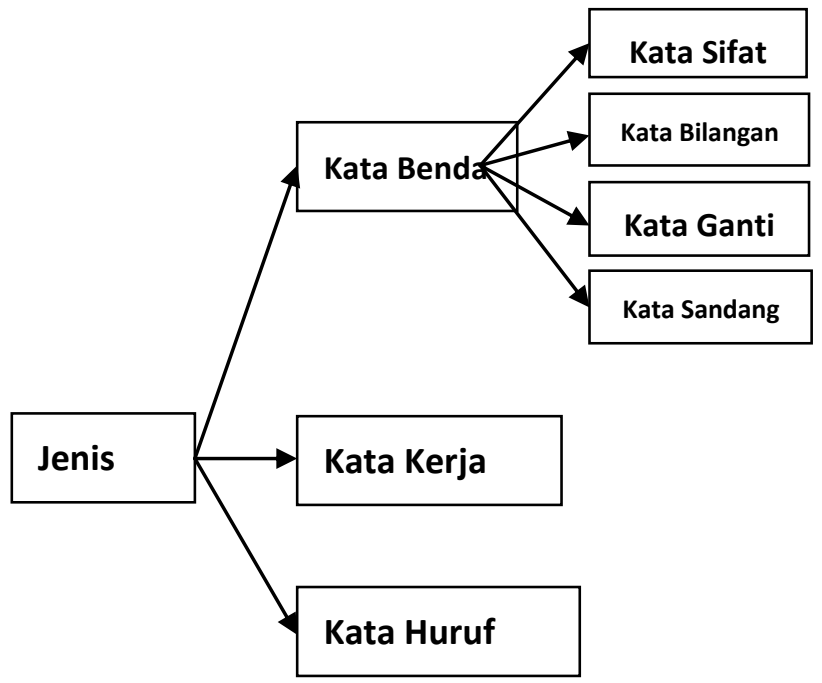

Berdasarkan kajian ilmu Nahwu, masing-masing kelas kata di atas masih dapat diklasifikasi menjadi beberapa bagian, yaitu:

a. Jenis Kata Benda (Isim), dilihat dari perspektif I'rab dan Bina':

1) Isim Mu'rab, meliputi: rafa', nashab, dan khafadl. ${ }^{19}$

2) Isim Mabni, meliputi: kata ganti (dlamir), ism al-isyarah, ism al-maushul, ism al-syarth, isim al-istifham, kata bilangan (isim al-'adad) dari $11-19$ kecuali hitungan 12, zharf mabni, dan ism al-fi'l. ${ }^{20}$

b. Jenis Kata Kerja (Fi'il), dilihat dari perspektif I'rab dan Bina':

1) Fi'il Mu'rab hanya fi'il mudlari' yaitu kata kerja bertempo sekarang (bermakna 'sedang') atau akan datang.

19 Fuad Ni'mah, Mulakkhas Qawa'id alLughah al-'Arabiyyah, (Surabaya: al-Hidayah, tt.), Juz I, h. 23-24.

20 Fuad Ni'mah, Mulakkhas Qawa'id alLughah al-'Arabiyyah, h. 111. 
2) Fi'il Mabni, meliputi: fi'il madly yaitu kata kerja yang bertempo lampau (bermakna 'telah') dan fi'il amar yaitu kata kerja perintah.

c. Jenis Kata Huruf, terbagi menjadi dua yaitu:

1) Huruf khusus kata kerja ( $\left.f i^{\prime} i l\right)$, meliputi: huruf nashab, huruf jazm, o dan yang bermakna ‘tidak' (ما و لا النافيتان), قد , dan السين و سوف.

2) Huruf khusus kata benda (isim), meliputi: huruf jar, إن ؤخواتها, huruf nida', إلا sebagai huruf istitsna', wawu ma'iyyah (wawu yang bermakna 'bersama/beserta'), dan lam ibtida' (lam yang berada di kata yang berposisi sebagai mubtada').

3) Huruf yang bisa masuk pada kata kerja $\left(f i^{\prime} i l\right)$ dan kata benda (isim) sekaligus, meliputi: huruf athaf, hamzah dan هل istifham (kata tanya), wawu hal, dan lam qasam (bermakna sumpah). ${ }^{21}$

Untuk lebih memudahkan para pembaca memahami klasifikasi kata yang telah dipaparkan panjang lebar di atas, berikut ini peneliti membuat bagan ikhtishar-nya.

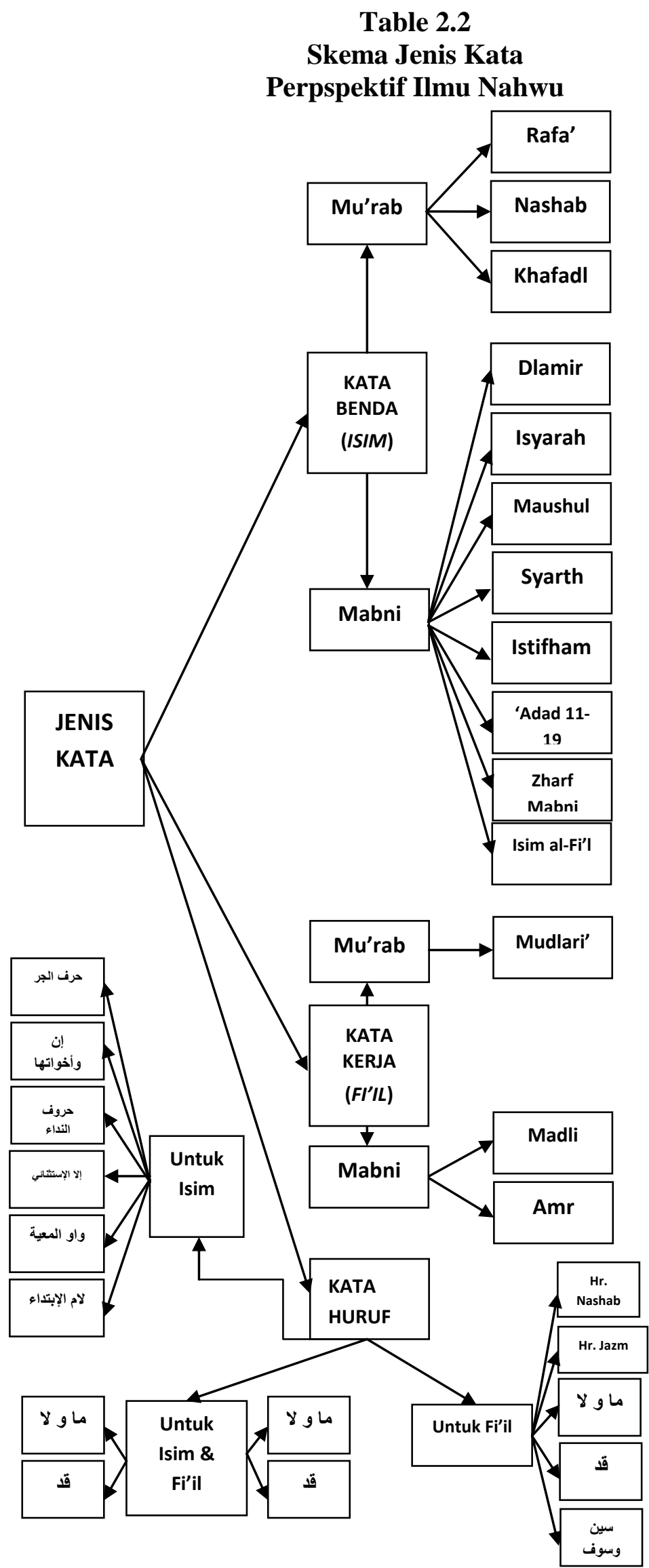

21 Fuad Ni'mah, Mulakkhas Qawa'id alLughah al-'Arabiyyah, h. 150 - 151. 
Sedangkan berdasarkan telaah ilmu Sharf, masing-masing kelas kata di atas masih dapat diklasifikasi menjadi beberapa bagian, yaitu:

a. Jenis Kata Benda (Isim), dilihat dari perspektif: ${ }^{22}$

1) Konstruksinya ( من حيث بنية الإسم (), meliputi: Shahih Akhir dan Ghairu Shahih Akhir. Shahih Akhir yaitu kata benda yang huruf belakangnya bukan salah satu dari huruf alif, ya', atau hamzah yang didahului

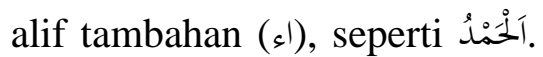

Ghairu Shahih Akhir yaitu kata benda yang huruf belakangnya terdiri dari salah satu hurufhuruf di atas. Jika diakhiri dengan huruf alif yang disebut ism al-maqshur seperti النِّكُى bila diakhiri dengan huruf $y a$ ' disebut ism al-manqush seperti الهًادِين dan manakala diakhiri dengan huruf hamzah yang didahului alif tambahan (s) disebut ism al-mamdud seperti 23

2) Ketertentuannya ( من حيث تعيين (الإسم ), meliputi: Nakirah (tak tertentu) dan Ma'rifah (tertentu). Ma'rifah masih terbagi menjadi tujuh bagian yaitu: kata ganti (dlamir), kata nama ('alam), kata petunjuk (isyarah), kata sambung/penghubung (maushul), kata yang dimsuki ال ta'rif, kata yang disandarkan pada ma'rifah (al-mudlaf ila

${ }^{22}$ Klasifikasi kata dari berbagai perspektif ini juga dirangkum dari konstruksi kata yang ditulis oleh Fu'ad Ni'mah dalam kitabnya. Selengkapnya silakan baca: Fuad Ni'mah, Mulakkhas Qawa'id al-Lughah al'Arabiyyah, Juz II hingga lembaran terakhir.

23 Fuad Ni'mah, Mulakkhas Qawa'id alLughah al-'Arabiyyah, Juz. II, h. 8-9. ma'rifah), dan munada maqshud. $^{24}$

3) Pemakaian jenisnya (من حيث نوع الإسم (ا) meliputi: mudzakkar (untuk jenis laki-laki) seperti أب yang artinya 'ayah' dan حصان yang berarti 'kuda', dan muannats (untuk jenis perempuan) seperti أم yang artinya 'ibu' dan حديقة yang berarti 'kebun'. Baik, mudzakkar maupun muannats, keduanya sama-sama ada yang haqiqi (benar-benar bermakna laki-laki atau permpuan) seperti أم dan pada contoh di atas, dan ada yang lafzhi (secara lafal menunjukkan laki-laki atau perempuan tetapi maknanya tidak untuk keduanya) seperti dan حديقة pada contoh di atas, sebab حصان tidak untuk kuda laki-laki saja, begitu pula contoh حديقة bukan untuk kebun perempuan karena tidak ada kebun laki-laki dan kebun perempuan. $^{25}$

4) Kuantitas kandungan maknanya ( من حيث عدد معنى (الإسم (bermakna tunggal) seperti (seorang muslim lakilaki), mutsanna (bermakna dua) seperti مسلمَّيْنِ atau (dua orang muslim laki-laki), dan jama' (bermakna banyak)

24 Tiga macam ma'rifah yang terakhir disingkat menjadi المعرف بأداة التعريف. Lihat: Abdullah Ibu 'Aqil, Syarh Ibnu 'Aqil, (Indonesia: al-Haramain, tt.), Juz I, h. 154 dan seterusnya.

${ }^{25}$ Musthafa al-Ghulayaini, Jami' al-Durus al'Arabiyah, (Beirut: al-Maktabah al-'Ashriyyah, 2003), Juz I, h. 75. 
yang untuk laki-laki disebut jama' mudzakkar salim seperti مسلمِيْنَ atau (banyak lakilaki muslim), dan yang untuk perempuan disebut jama' muannats salim seperti مسلمات (banyak perempuan muslimat), serta untuk laki-laki dan perempuan yang cara bacanya berubah dari cara baca mufradnya disebut jama' taksir seperti طُلَّبَّ (banyak siswa dan siswi) yang bacaan mufrad-nya adalah طَالِّب yaitu tha' fathah pada mufrad-nya berubah bacaannya menjadi tha' dlammah pada jama' taksirnya. $^{26}$

5) Susunannya ( من حيث تركيب الإسم (), meliputi: jamid (asal kata/al-ashl al-wahid) dan musytaqq (kata bentukan dari asal kata). Isim Jamid ada dua ism al-dzat/ism al-jinsi dan mashdar/ism al-ma'na. ${ }^{27}$ Sedangkan musytaqq itu ada tujuh, yaitu: ism al-fa'il (juga shighat mubalaghah), ism almaf'ul, shifat musyabbahah, ism al-tafdlil, ism al-zaman, ism al-makan, ism al-alat. ${ }^{28}$ Klasifikasi kata benda dari sudut pandang tarkib-nya ini yang selanjutnya lebih banyak berbicara tentang tashrif, yaitu perubahan kata dasar atau akar kata (al-ashl al-wahid) ke beberapa contoh yang berbedabeda dengan tujuan untuk

26 Fuad Ni'mah, Mulakkhas Qawa'id alLughah al-'Arabiyyah, (Surabaya: al-Hidayah, tt.), Juz II, h. 26.

27 Fuad Ni'mah, Mulakkhas Qawa'id alLughah al- 'Arabiyyah, Juz II, h. 30

28 Fuad Ni'mah, Mulakkhas Qawa'id alLughah al- 'Arabiyyah, Juz II, h. 38 memeroleh makna yang dikehendaki. $^{29}$

b. Jenis Kata Kerja (Fi'il), dilihat dari perspektif: ${ }^{30}$

1) Konstruksinya ( من حيث بنية الفعل), meliputi: Fi'il Shahih yaitu kata kerja yang salah satu huruf dasarnya bukan huruf 'illah (bukan و، ا، و), dan Fi’il Mu'tall yaitu kata kerja yang salah satu huruf dasarnya terdapat huruf 'illah di atas. Fi'il Shahih ada tiga bagian, yaitu mahmuz (kata kerja yang salah satu huruf dasarnya terdapat huruf hamzah), mudla" af tsulatsi (kata kerja yang 'ain dan lam fi'il-nya sejenis/sama), dan salim (kata kerja yang salah satu huruf dasarnya bukan hamzah, huruf yang sama antara 'ain dan lam fi'il, serta bukan huruf 'illah). Fi'il Mu'tall terbagi menjadi tiga bagian. ${ }^{31}$

Menurut Syeikh Ali Hisyam al-Kailani terbagi lima, yaitu mitsal (huruf 'illah berada di $f a$ ' fi'il), ajwaf (huruf 'illah berada di 'ain fi'il), naqish (huruf 'illah berada di lam fi'il), lafif (huruf 'illah double pada $f a$ ' fi'il dan lam fi'il, atau pada 'ain fi'il dan lam fi'il), mu'tall fa'- 'ainlam (huruf 'illah berada pada fa', 'ain, dan lam fi' il). ${ }^{32}$

2) Susunan atau komponen hurufnya (من حيث تركيب الفعل), meliputi: fi'il mujarrad dan

\footnotetext{
${ }^{29}$ Ali bin Hisyam al-Kailani, Syarh Kailani 'Izzi, (Indonesia: Dar Ihya' al-Kutub al-'Arabiyyah, tt.), h. 2 .

30 Fuad Ni'mah, Mulakkhas Qawa'id alLughah al-'Arabiyyah, Juz II hingga lembaran terakhir.

31 Fuad Ni'mah, Mulakkhas Qawa'id alLughah al-'Arabiyyah, Juz II, h. 63 - 64.

${ }^{32}$ Ali bin Hisyam al-Kailani, Syarh Kailani 'Izzi, (Indonesia: Dar Ihya' al-Kutub al-'Arabiyyah, tt.), h. $16-30$.
} 
fi'il mazid. Mujarrad artinya kata kerja asli, belum diberi imbuhan seperti (membaca), sedangkan Mazid adalah kata kerja yang telah mendapat

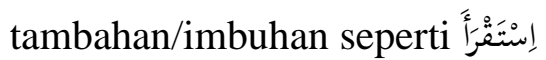
(membaca situasi/meneliti). قَرًَ yang mendapat tambahan/imbuhan - $ت^{33}$

3) Waktu terjadinya suatu pekerjaan ( من حيث زمن وقوع الفعل), meliputi: fi'il madly (kata kerja waktu lampau saja), fi'il mudlari' (kata kerja waktu sekarang/mendatang), dan fi'il amr (kata kerja waktu mendatang saja). ${ }^{34}$

4) Jangkauan 'amal-nya ( من حيث (معمول الفعل), meliputi: fi'il lazim dan muta'addi. Fi'il Lazim adalah kata kerja yang tidak membutuhkan kehadiran objek dalam susunan kalimat. Sedamgkan Fi'il Muta'addi yaitu adalah kata kerja yang membutuhkan kehadiran objek dalam susunan kalimat. ${ }^{35}$

5) Penyebutan subjek dan من حيث ذكر فاعل النعل (idaknya (وعدمه), meliputi Fi'il Mabni Ma'lum dan Fi'il Mabni Majhul. Yang pertama adalah kata kerja yang diikuti objek, sedangkan yang kedua ialah kata kerja yang tidak diikuti objek. Yang pertama disebut transitif dan yang kedua

33 Ibrahim bin Abdul Wahhab al-Zanjani, dalam Abdullah al-Dankizi, Matn al-Bina' wa al-Asas, (Surabaya: Maktabah al-Hidayah, tt.), h. 16.

34 Fuad Ni'mah, Mulakkhas Qawa'id alLughah al- 'Arabiyyah, Juz II, h. 69.

35 Fuad Ni'mah, Mulakkhas Qawa'id alLughah al-'Arabiyyah, Juz II, h. 78. dikatakan intransitif dalam bahasa Indonesia. ${ }^{36}$

6) Tashrif-nya ( من حيث تصريف الفعل), meliputi Fi'il Jamid dan Fi'il Mutasharrif. Yang kedua masih dibagi menjadi dua bagian, yaitu: Fi'il Mutasharrif Sempurna dan Fi'il Mutasharrif Tak Sempurna terdapat pada أخوات كان، أفعال 37 37 3قالمقاربة، أفعال الشروع

Untuk mempermudah memahami klasifikasi kata benda dan kata kerja yang telah dipaparkan di atas, peneliti akan meringkasnya dalam bagan berikut ini:
36 Fuad Ni'mah, Mulakkhas Qawa'id alLughah al-'Arabiyyah, Juz II, h. 81. Bandingkan pula dengan S. Effendi, Djoko Kendjono, dab Basuki Suhardi, Tata Bahasa Dasar Bahasa Indonesia, (Bandung: Remaja Rosdakarya, 2015), cet. I, h. 81 83.

37 Fuad Ni'mah, Mulakkhas Qawa'id alLughah al-'Arabiyyah, Juz II, h. 83 - 84. 


\section{Bagan 2.3}

Skema Jenis Kata Benda Perpspektif Ilmu Sharf
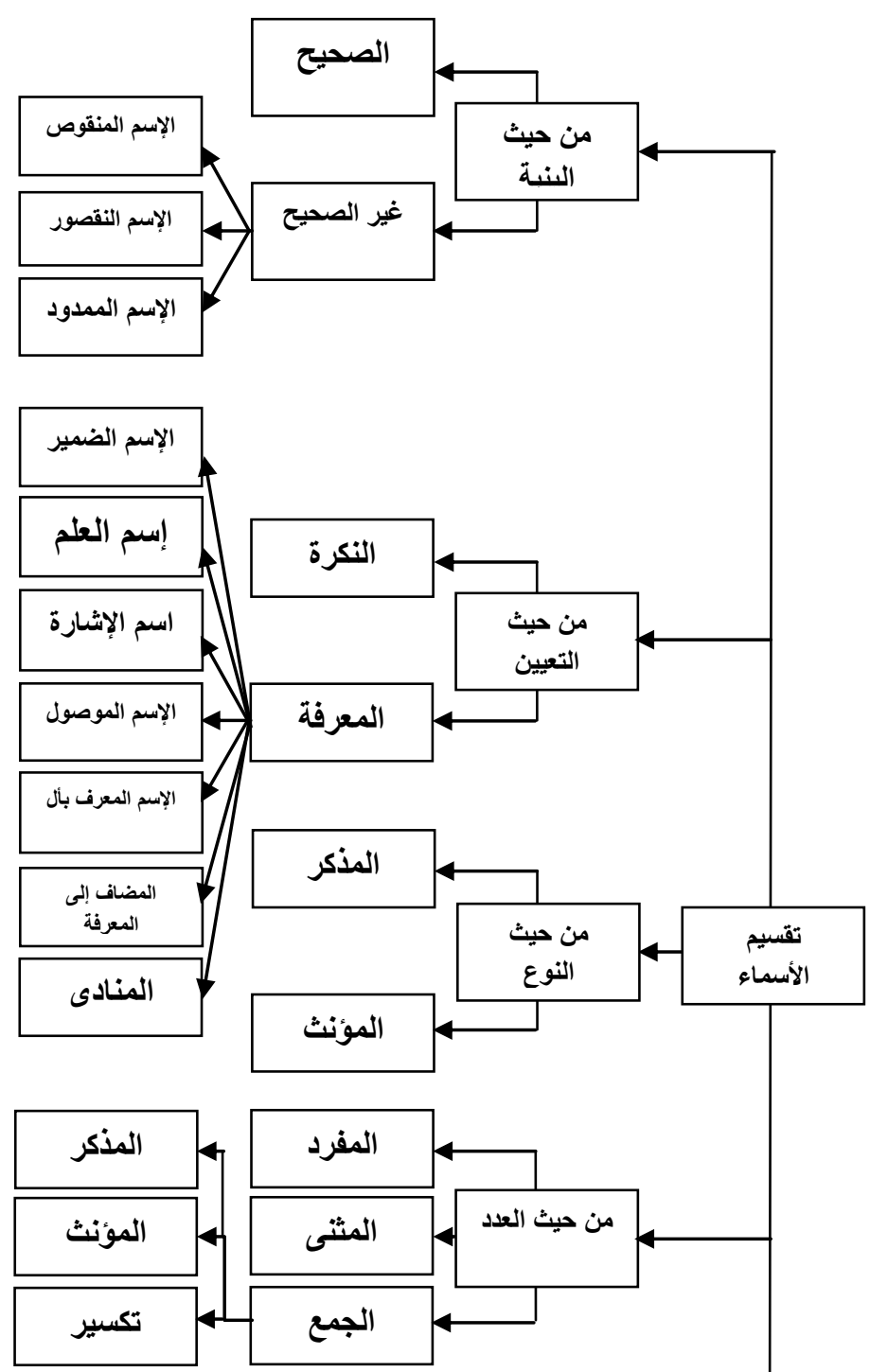

\section{Bagan 2.4}

Skema Jenis Kata Kerja Perpspektif Ilmu Sharf

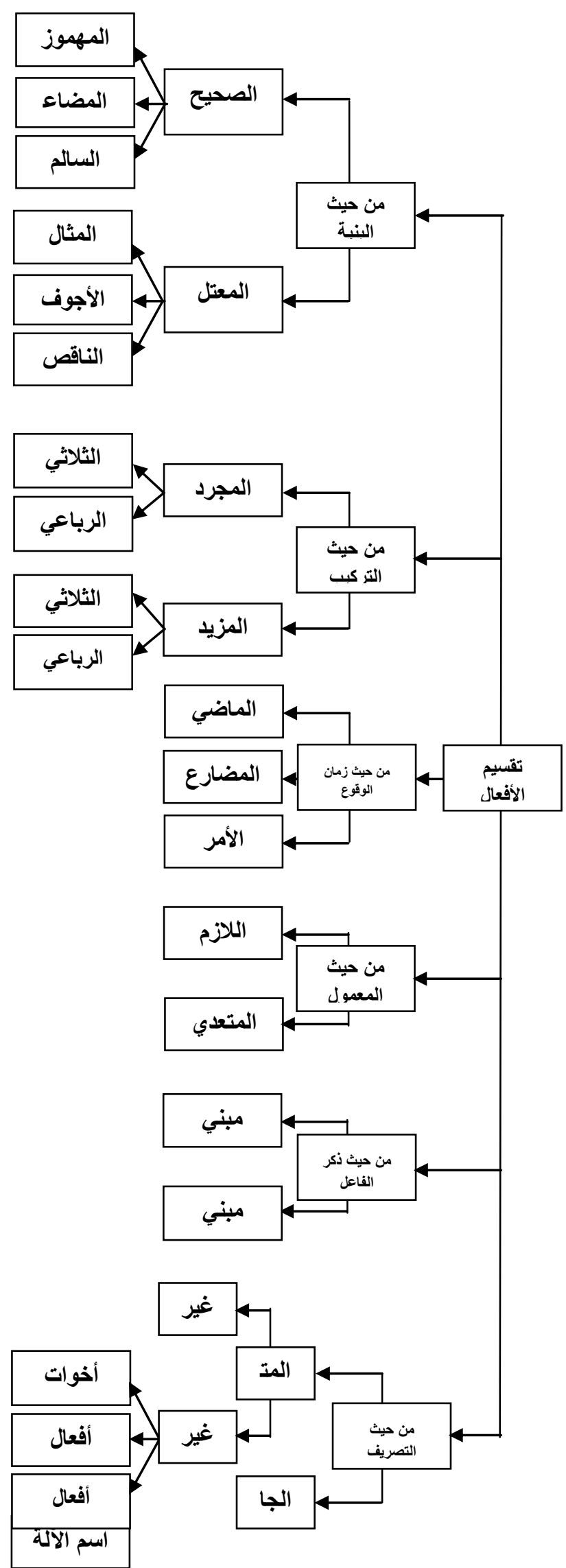




\section{Makna Kata}

Pembahasan makna kata miripmirip dengan pembahasan diksi, yaitu penggunaan kata yang tepat atau pilihan kata yang tepat dalam bahasa tulis mau pun lisan. Pemilihan diksi yang tepat tidak dapat dilepaskan dari kamus, begitu pula pemaknaan yang benar atas kata asing juga tidak dapat dipisahkan dari kamus. ${ }^{38}$ Dengan demikian, peran kamus dalam pembelajaran bahasa sangat tinggi.

Salah satu keterampilan dalam berbahasa adalah keterampilan membaca (مهارة القراءة). Keterampilan membaca kitab kuning merupakan bagian dari keterampilan membaca dalam bahasa Arab. Mamduh Nuruddin -sebagaimana dikutip Acep Hermawan - mengatakan bahwa kosa kata adalah aspek vital dalam pembelajaran bahasa Arab, karena bahasa Arab memiliki banyak aspek sejak dari bunyi huruf, bangunan kata, susunan kalimat, dan makna. Makna adalah kandungan yang dimaksud atau yang ditunjuk oleh suatu kata atau kalimat. ${ }^{39}$ Untuk memahami makna suatu kalimat, seseorang perlu mengetahui makna kata terlebih dahulu. Untuk mengetahui makna kata dapat dilakukan dengan cara mencarinya dalam kamus, sering menemukannya di buku bacaan, dan banyak menyimak kata-kata asing, dalam hal ini kata-kata Arab. ${ }^{40}$

Pencarian makna dalam kamus tidak selamanya tepat saat dipakai dalam kalimat Arab. Hal ini disebabkan oleh, suatu kata kadang menjadi term tersendiri dalam satu

${ }^{38}$ Silakan bandingkan antara: E. Zainal Arifin dan S. Amran Tasai, Cermat Berbahasa Indonesia untuk Perguruan Tinggi, (Jakarta: Akademika Presindo, 2010), cet. XII, h. 28; dan Acep Hermawan, Metodologi Pembelajaran Bahasa Arab, (Bandung: Remaja Rosdakarya, 2014), cet. IV, h. 268-269.

${ }^{39}$ Acep Hermawan, Metodologi Pembelajaran Bahasa Arab, (Bandung: Remaja Rosdakarya, 2014), cet. IV, h. 270.

${ }^{40}$ Acep Hermawan, Metodologi Pembelajaran Bahasa Arab, h. 270. disiplin ilmu tertentu dan menjadi term berbeda dalam disiplin ilmu yang lain, seperti kata al-kalam dalam ilmu tauhid yang terminologinya bermakna firman Allah, dan dalam ilmu fiqh dipahami sebagai ungkapan yang dapat dipaham walaupun satu huruf yang menjadi salah satu pembatal salat $^{41}$ dan dalam ilmu nahwu dipahami sebagai suatu ungkapan huruf-huruf hijaiyah yang tersusun dan dapat dipahami serta pelafalannya dilakukan secara sengaja atau berbahasa Arab. ${ }^{42}$

Dengan demikian, keterampilan gramatikal merupakan keterampilan berbeda dengan keterampilan memaknai, sebab orang yang sudah paham gramatikal bahasa Arab tidak serta merta mengantarkannya mampu memaknai teks-teks Arab. Begitu pula sebaliknya, orang yang menguasai kosa kata bahasa Arab tidak mesti dia mampu berbahasa Arab dengan baik.

Sungguh pun kamus dapat membantu seseorang dalam memaknai kata dan kalimat, namun dalam praktik pencarian makna dalam kamus manual berbeda-beda antar satu kamus dengan kamus yang lain. Kamus Lisan al-Arab menggunakan huruf akhir sebagai patokan pencariannya, misalnya seseorang hendak mencari makna sَرْ maka orang tersebut harus

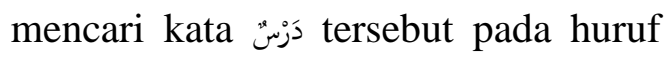
. 43

Kamus al-Ashri berbeda lagi dalam pencarian makna mufradat, yaitu seseorang yang hendak mencari makna يَدْرُسُ maka orang tersebut tinggal mencari kata يَدْرُسُ

41 Hasan al-Kafrawi, Syarh al-'Allamah alSyaikh Hasan al-Kafrawi, (Surabaya: Syirkah Bungkul Indah, tt.), h. 9.

42 Ahmad Zaini Dahlan, Mukhtashar Jiddan, (Indonesia: al-Haramain, tt.), h. 4.

43 Silakan perhatikan: Muhammad bin Mukram bin 'Ali Ibnu Manzhur, Lisan al-'Arab, (Beirut: Dar Shadir, 1414 H.), cet. III. 
langsung. ${ }^{44}$ Sedangkan kamus yang lain pada umumnya, seperti Kamus Yunus, al-Munawwir, al-Munjid, dan semacamnya, bila seseorang hendak mencari makna kata دَرَّنَ hendaknya orang tersebut mencari kata درس terlebih dahulu dan di bawah kata tersebut akan diuraikan kata-kata lain sebagai turunannya. ${ }^{45}$

Contoh lain, seseorang yang hendak mencari makna إِ kamus di atas tidak bisa langsung

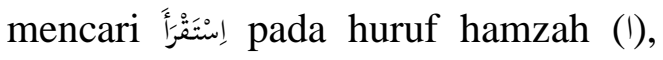
namun dia harus mencarinya terlebih dahulu pada huruf قaitu kata قرأ

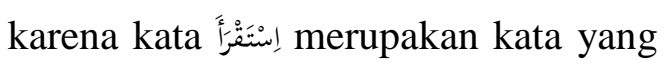
berimbuhan س ت ا I. Hal ini sama dengan seseorang yang hendak mencari makna 'penampungan' tidak bisa langsung dicari di huruf ' $p$ ' dalam kamus Bahasa Indonesia, melainkan harus dicari di huruf ' $\mathrm{t}$ ' dengan kata 'tampung' terlebih dahulu, baru kata 'tampung' dicari kata-kata turunannya dan di situlah akan dijumpai kata 'penampungan.'

Untuk kepentingan pencarian makna dalam kamus Arab yang biasa digunakan dalam pembelajaran bahasa Arab, termasuk kitab kuning, dibutuhkan seseorang yang memiliki kemampuan membedakan kata dasar dan kata berimbuhan. Dalam pembelajaran bahasa Arab atau kitab kuning dapat didalami materi klasifikasi kata dari segi mujarrad dan mazid-nya atau materi al-ashl alwahid dan perubahannya pada matapelajaran Sharf.

${ }^{44}$ Atabik Ali dan A. Zuhdi Muhdlor, Kamus Kontemporer Arab-Indonesia, (Jogjakarta: Multi Karya Grafika, 2003).

45 Achmad Warson Munawwir, Kamus AlMunawwir Arab-Indonesia Terlengkap, (Surabaya: Pustaka Progresif, 1997), cet. XIV. Bandingkan dengan: Mahmud Yunus, Kamus Arab-Indonesia, (Jakarta: Hidakarya Agung, 1989).

\section{b. Tarkib dan Maharah al-Qira'ah \\ 1. Definisi Tarkib dan Qira'ah dan Keterkaitan antar Keduanya}

Tarkib adalah aturan-aturan mengenai penggunaan bahasa Arab yang digunakan sebagai media untuk memahami kalimat. Kalimat yaitu satuan gramatikal yang secara relative berdiri sendiri, memunyai pola intonasi final, baik secara aktual mau pun secara potensial terdiri dari klausa. Klausa diartikan sebagai bentuk linguistik yang terdiri atas subjek dan predikat. ${ }^{46}$

Qira'ah atau membaca merupakan keterampilan berbahasa yang tidak mudah dan tidak pula sederhana, tidak sekedar membunyikan huruf-huruf atau katakata, melainkan juga melibatkan berbagai kerja akal dan pikiran saat pembacaan berlangsung. Membaca berarti melibatkan semua bentuk berpikir, memberi penilaian, memberi keputusan, menganalisis, dan mencari pemecahan masalah. Oleh sebab itu, seseorang yang sedang membaca teks harus berhenti sejenak atau mengulanginya lagi beberapa kata atau kalimat yang telah dibaca guna berpikir dan memahami apa yang dimaksud oleh bahan bacaan tersebut. ${ }^{47}$

Berdasarkan deskripsi di atas, pembelajaran tarkib tentu kurang berarti bila tidak diikuti dengan praktik membaca secara langsung teks-teks arab. Syaiful Mustofa mengatakan bahwa, seorang siswa tidak cukup menghafal kaidah-kaidah nahwu saja, melainkan ia harus menerapkannya dengan cara membaca dan menuliskan teks-teks Arab berdasarkan kaidah-kaidah yang telah dihafalnya. Dengan demikian, takrib

46 Syaiful Mustofa, Strategi Pembelajaran Bahasa Arab Inovatif, (Malang: UIN-MALIKI PRESS, 2011), h. $93-95$.

47 Bisri Mustofa dan M. Abdul Hamid, Metode dan Strategi Pembelajaran Bahasa Arab, (Malang: UIN-MALIKI PRESS, 2012), cet. II, h. 99. 
bukan suatu tujuan akhir di mana siswa sudah cukup belajar sampai di situ, melainkan ia sebagai sarana/wasilah untuk mencapai tujuan yaitu maharah al-qira'ah wa alkitabah. $^{48}$

2. Model Pembelajaran Tarkib dan Qira'ah

Ada dua model pembelajaran tarkib dan qira'ah, yaitu model qiyasi (deduktif) dan istiqra'i (induktif). Kedua mode ini disebut dengan penalaran tidak langsung dalam ilmu logika. ${ }^{49}$ Berikut penjelasan masingmasing:

a) Qiyasi (Deduktif)

$\begin{array}{lcr} & \text { Model ini } & \text { merupakan } \\ \text { bentuk } & \text { kegiatan } & \text { pembelajaran } \\ \text { yang } & \text { lumrah } & \text { digunakan. }\end{array}$

Kegiatannya dimulai dari belajar teori atau konsep-konsep yang ada dalam ilmu nahwu dan sharf berikut contoh-contohnya, lalu ditampilkan contoh-contoh lain sebagai bentuk penalaran dari contoh yang ada dalam teori atau konsep. adalah:

Kelebihan model Qiyasi

1) Tujuan pembelajaran lebih spesifik;

2) Aplikasi pembelajaran mudah dan cepat;

3) Siswa mudah dan cepat paham;

4) Terhindar dari kesalahan dengan contoh-contoh yang diajarkan; dan

5) Tidak menekankan adanya hafalan. adalah:

Sedangkan kelemahanya

1) Pemahaman siswa mudah luntur;

48 Syaiful Mustofa, Strategi Pembelajaran Bahasa Arab Inovatif, (Malang: UIN-MALIKI PRESS, 2011), h. 92.

49 Surajiyo, Sugeng Astanto, Sri Andiani, Dasar-dasar Logika, (Jakarta: Bumi Aksara, 2014), cet. VII, h. 59.
2) Adanya ketergantungan pada orang lain;

3) Siswa kurang aktif berpikir dan mengemukakan pendapat; dan

4) Kesulitan dalam qawa'id yang bersifat juz'iyyah. ${ }^{50}$

b) Istiqra' $i$ (Induktif)

Model Istiqra'i ini merupakan kebalikan dari model Qiyasi, yaitu para siswa dihadapkan pada contoh-contoh yang beraneka ragam mengenai konsep yang akan diajarkan, lalu mereka diminta melakukan klasifikasi atas contoh-contoh tersebut, dan terakhir ditarik kesimpulan dan kesimpulan tersebut merupakan konsep. ${ }^{51}$

Strategi inkuiri merupakan turunan dari model Istiqra'i ini dalam pembelajaran modern. Materi pelajaran tidak diberikan secara langsung dalam strategi ini. Strategi pembelajaran ini menekankan para siswa untuk mencari dan menyelidiki secara sistematis, kritis, logis, dan analitis, sehingga mereka menemukan simpulan ${ }^{52}$ atau konsep-konsep dari contoh atau fenomena yang ditampilkan guru, sedangkan guru berposisi sebagai fasilitator dan pendamping siswa dalam proses pembelajaran. ${ }^{53}$

Kelebihan penggunaan model Istiqra' $i$ yaitu:

1) Baik untuk menemukan tujuan qawa'id nahwu;

50 Syaiful Mustofa, Strategi Pembelajaran Bahasa Arab Inovatif, h. 97 - 100.

51 Muhammad Nur al-Ibrahimy, 'Ilmu alManthiq, (Surabaya: Maktabah Sa'd bin Nashir nabhan, tt.), h. 85.

${ }^{52}$ Suryadi, Strategi Pembelajaran Pendidikan Karakter, (Bandung: Remaja Rosdakarya, 2013), cet. II, h. 115.

53 Wina Sanjaya, Strategi Pembelajaran Berorientasi Standar Proses Pendidikan, (Jakarta: Kencana Prenada Media Group, 2014), cet. XIV, h. $193-195$. 
2) Siswa mampu melakukan penalaran hingga penyimpulan dari hal yang sifatnya umum;

3) Memberikan makna yang jelas dan mudah dipraktikkan oleh siswa;

4) Contoh-contohnya menggunakan uslub yang mudah dipahami; dan

5) Meningkatkan motivasi guru. Sedangkan kelemahannya adalah:

1) Lambat mengetahui informasi karakteristik siswa;

2) Tidak efisien karena banyaknya contoh-contoh; dan

3) Contoh-contoh seringkali parsial dan tidak sesuai dengan tingkat kemampuan siswa. ${ }^{54}$

\section{Teknik Pembelajaran Tarkib dan} Qira'ah

Teknik pembelajaran lebih operasional ketimbang model pembelajaran. Baik model pembelajaran deduktif dan induktif, keduanya sama-sama memiliki teknik praktis dalam penerapannya dalam pembelajaran. Penentuan teknik pembelajaran disesuaikan dengan karakteristik materi atau tujuan pembelajaran yang harus disampaikan. $^{55}$ Acep Hermawan menegaskan bahwa kompetensi pada materi Qira'ah tidak hanya kemampuan siswa membaca teks Arab saja, melainkan ada kompetensi lain yang harus dikuasai secara simultan. Kompetensi tersebut yaitu: (1) kemampuan mengenali symbol-simbol tertulis dan ini merupakan ranah gramatikal (nahwu-sharf),

kemampuan memahami makna yang terkandung oleh teks Arab yang

54 Syaiful Mustofa, Strategi Pembelajaran Bahasa Arab Inovatif, h. 100 - 101.

${ }^{55}$ Lihat: Syaiful Bahri Djamarah dan Aswan Zain, Strategi Belajar Mengajar, (Jakarta: Rineka Cipta, 2006), cet. III, h. 80 dan 129 dan seterusnya. Bandingkan pula dengan: Hamdani, Strategi Belajar Mengajar, (Bandung: Pustaka Setia, 2011), h. 155; dan Roestiyah NK, Didaktik Metodik, (Jakarta: Bina Aksara, 1989), h. 68. dibaca, (3) kemampuan menyikapi makna yang terkandung pada teks tersebut, dan (4) kemampuan mengimplementasikan makna yang terkandung dalam kehidupan seharihari. $^{56}$

Berdasarkan hirarki
kompetensi di atas, teknik
pembelajaran pada materi tarkib dan qira'ah juga harus disesuaikan. Berikut ini tahapan-tahapan pembelajaran tarkib dan qira'ah khusus pada kompetensi pertama dan kedua pada pernyataan Acep Hermawan di atas:

a) Metode Harfiyyah Abajadiyyah Hijaiyyah

Metode ini adalah pengenalan huruf-huruf abjad atau huruf-huruf hijaiyah kepada siswa secara parsial. Pembelajaran ini sama dengan pembelajaran metode iqra' di mana siswa dituntun untuk mengetahui dan mampu membaca huruf-huruf hijaiyyah secara tepat. Kompetensi yang hendak dicapai dengan metode ini adalah siswa mampu membedakan huruf-huruf hijaiyyah antara yang satu dengan yang lain serta mampu membacanya dengan tepat. Contohnya adalah dan seterusnya. ${ }^{57}$

b) Metode Shautiyyah atau Metode Kalimat

\begin{tabular}{|c|c|}
\hline Setelah & seorang \\
\hline menguasai & kompetensi \\
\hline empelajari & baca \\
\hline
\end{tabular}
bersambung dalam satu kata atau kalimat (al-intiqal min al-huruf ila al-kalimat wa al-jumal). Seorang guru tidak lagi mengajarkan tiap huruf, tetapi sudah mengajarkan satu kata komplit atau beberapa

${ }^{56}$ Acep Hermawan, Metodologi Pembelajaran Bahasa Arab, (Bandung: Remaja Rosdakarya, 2014), cet. IV, h. 144.

57 Muhammad Ibrahim al-Khathib, Tharaiq Ta'lim al-Lughah al- 'Arabiyyah, (Riyadl: Maktabah alTaubah, 2003), h. 83. 
kata secara sekaligus, bahkan satu kalimat ata beberapa kalimat sekaligus. Misalnya, إِجْتَمَعَ, كَتَبَ dan sebagainya. ${ }^{58}$

c) Metode Kaidah dan Terjemah

Di dalam qira'ah, pada siswa tidak hanya dituntut mampu membaca, tetapi mereka juga diminta mengetahui makna kata yang dibaca hingga makna kalimat secara totalitas dari kumpulan kata-kata yang menjadi unsur pembentuknya. Dalam tarkib katakata dengan segala ragamnya berbaur menjadi satu membentuk kalimat, sedangkan secara teoritiskoseptual siswa dipelajari tentang macam-macam dan bentuk kata beserta tarkib-nya.

Maka dari itu, analisis (tahlil) kata dan kalimat menjadi hal yang mesti dilakukan dalam pembelajaran qira'ah agar makna yang diprediksikan tidak melenceng dari kata dan kalimatnya. Yang dimaksud dengan analisis (tahlil) di sini yaitu memisah-misah atau mengurai masing-masing kata yang ada dalam kalimat yang dipelajari, bahkan mengurai huruf yang menjadi unsur pembentuk kata-kata yang ada pada kalimat tersebut. $^{59}$

Dalam praktiknya, analisis dilakukan pada gramatikal, penghafalan kosa kata, penerjemahan wacana (teks Arab), dan latihan menulis. Metode kaidah dan terjemah ini merupakan metode tertua dan mengakar kuat dalam tradisi pembelajaran bahasa Yunani kuno dan bahasa Latin di Eropa. Cara belajar seperti ini relevan dengan pembelajaran bahasa yang menggunakan naskah

58 Muhammad Ibrahim al-Khathib, Tharaiq Ta'lim al-Lughah al- 'Arabiyyah, h. 84.

59 Muhammad Ibrahim al-Khathib, Tharaiq Ta'lim al-Lughah al- 'Arabiyyah, h. 94. klasik sebagai objek kajiannya, ${ }^{60}$ termasuk dalam mempelajari bahasa kitab kuning di pesantren. Menurut Ba'labaki sebagaimana dikutip Acep-dasar pokok metode ini adalah hafalan kaidah, analisis gramatika terhadap wacana, lalu terjemah ke dalam bahasa pengantar atau bahasa sehari-hari. Kompetensi berbahasa yang dituntut dengan penggunaan metode ini bukan bahasa aktif, melainkan bahasa pasif; bukan bahasa komunikatif, tetapi bahasa logis berdasarkan kaidah-kaidah tata bahasa. Dengan demikian, ada dua aspek penting dalam metode kaidah dan terjemah ini, yaitu: kemampuan menguasai kaidah tata bahasa dan kemampuan menerjemahkan. $^{61}$

Langkah-langkah

penggunaan metode Kaidah dan Terjemah adalah:

1) Guru melakukan kegiatan awal atau pendahuluan yang dapat diisi dengan apersepsi, tes kemampuan awal, dan lainnya;

2) Guru memberikan pengenalan dan definisi kaidah-kaidah yang berkaitan dengan wacana yang akan diberikan kepada siswa agar kaidah dan definisi tersebut dihafal untuk bahan latihan pada wacana yang akan diberikan;

3) Guru memberikan makna kosa kata yang sekiranya sulit dipaham oleh siswa;

4) Guru memberikan wacana berupa teks Arab, lalu dia mengajak para siswa untuk menerjemahkan kata demi kata, kalimat demi kalimat, sampai paragraf demi paragraf, dan mereka juga diminta untuk

\footnotetext{
${ }^{60}$ Acep Hermawan, Metodologi Pembelajaran Bahasa Arab, (Bandung: Remaja Rosdakarya, 2014), cet. IV, h. $169-170$.

${ }^{61}$ Acep Hermawan, Metodologi Pembelajaran Bahasa Arab, h. 171.
} 
menganalisis wacana tersebut berdasarkan kaidah-kaidah yang dijelaskan sebelumnya;

5) Guru memberikan daftar kosa kata di luar kosa kata yang terdapat pada wacana dan siswa harus menghafal dan menerjemahkannya;

6) Guru memberikan pekerjaan rumah yang berupa persiapan terjemahan untuk dibahas pada pertemuan berikutnya. ${ }^{62}$

\section{SIMPULAN}

Dengan demikian, keterampilan gramatikal merupakan keterampilan berbeda dengan keterampilan memaknai, sebab orang yang sudah paham gramatikal bahasa Arab tidak serta merta mengantarkannya mampu memaknai teks-teks Arab. Begitu pula sebaliknya, orang yang menguasai kosa kata bahasa Arab tidak mesti dia mampu berbahasa Arab dengan baik. Akan tetapi, dengan memahami gramatika bahasa Arab, juga akan cenderung mampu memahami tarkib. Gramatika merupakan langkah awal, atau disebut juga alat untuk membuka sumber-sumber referensi yang terdiri dari teks-teks Arab sehingga sangat penting untuk difahami, termasuk bagi para pemula. Menyusun materi atau pun silabus dalam bimbingan membaca kitab, tidak akan lepas dari teori-teori yang berkaitan dengan pembelajaran bahasa Arab, mengingat keterampilan membaca kitab adalah salah satu dari keterampilan berbahasa. Oleh karena itu, pembelajaran bahasa Arab dan membaca kitab adalah dua hal yang sangat relevan dan memiliki keterkaitan yang sangat signifikan.

\section{DAFTAR PUSTAKA}

'Abbas Hasan, al-Nahwu al-Wafi, Dar alMa'arif, Juz I

Abdullah Ibu 'Aqil, Syarh Ibnu 'Aqil, (Indonesia: al-Haramain, tt.), Juz I

Abu al-Hasan Ali bin Hisyam al-Kailani, Syarh Kailani Izzi, (Indonesia: Maktabah Dar al-Kutub al-Arabiyah)

${ }^{62}$ Acep Hermawan, Metodologi Pembelajaran Bahasa Arab, h. 173 - 174.
Abu Bakr Muhammad bin al-Sirri Ibnu Siraj, al-Ushul fi al-Nahwi, (Beirut: Mu'assasah al-Risalah, tt.)

Acep Hermawan, Metodologi Pembelajaran Bahasa Arab, (Bandung: Remaja Rosdakarya, 2014), cet. IV

Achmad Warson Munawwir, Kamus AlMunawwir Arab-Indonesia Terlengkap, (Surabaya: Pustaka Progresif, 1997), cet. XIV

Afifuddin Muhajir, al-Luqmah al-Saighah $f i$ al-Risalah al-Nahwiyyah, (Situbondo: PP. Salafiyah Syafi'iyah Sukorejo, 2013)

Ahmad bin Muhammad al-Andalusy, alHudud fi 'Ilmi al-Nahwi, (Madinah: alJami'ah al-Islamiyyah, 2001)

Ahmad Zaini Dahlan, Mukhtashar Jiddan, (Indonesia: al-Haramain, tt.)

Ali bin Hisyam al-Kailani, Syarh Kailani 'Izzi, (Indonesia: Dar Ihya' al-Kutub al'Arabiyyah, tt.)

Atabik Ali dan A. Zuhdi Muhdlor, Kamus Kontemporer Arab-Indonesia, (Jogjakarta: Multi Karya Grafika, 2003).

Bisri Mustofa dan M. Abdul Hamid, Metode dan Strategi Pembelajaran Bahasa Arab, (Malang: UIN-MALIKI PRESS, 2012), cet. II

E. Zainal Arifin dan S. Amran Tasai, Cermat Berbahasa Indonesia untuk Perguruan Tinggi, (Jakarta: Akademika Presindo, 2010), cet. XII

Fuad Ni'mah, Mulakkhas Qawa'id al-Lughah al-'Arabiyyah, (Surabaya: al-Hidayah, tt.), Juz I

Fuad Ni'mah, Mulakkhas Qawa'id al-Lughah al-'Arabiyyah, (Surabaya: al-Hidayah, tt.), Juz II

Hamdani, Strategi Belajar Mengajar, (Bandung: Pustaka Setia, 2011), h. 155; dan Roestiyah NK, Didaktik Metodik, (Jakarta: Bina Aksara, 1989)

Hasan al-Kafrawi, Syarh al-'Allamah alSyaikh Hasan al-Kafrawi, (Surabaya: Syirkah Bungkul Indah, tt.)

Ibnu Manzhur al-Anshari, Lisan al-Arab, Beirut: Dar Shadir, Juz XII

Ibrahim bin Abdul Wahhab al-Zanjani, dalam Abdullah al-Dankizi, Matn al-Bina' wa 
al-Asas, (Surabaya: Maktabah alHidayah, tt.)

Mahmud Yunus, Kamus Arab-Indonesia, (Jakarta: Hidakarya Agung, 1989).

Muhammad bin Mukram bin 'Ali Ibnu Manzhur, Lisan al-'Arab, (Beirut: Dar Shadir, 1414 H.)

Muhammad Ibrahim al-Khathib, Tharaiq Ta'lim al-Lughah al-'Arabiyyah, (Riyadl: Maktabah al-Taubah, 2003)

Muhammad Nur al-Ibrahimy, 'Ilmu alManthiq, (Surabaya: Maktabah Sa'd bin Nashir nabhan, tt.)

Musthafa al-Ghulayaini, Jami' al-Durus al'Arabiyah, (Beirut: al-Maktabah al'Ashriyyah, 2003), Juz I

Raji al-Asmar, al-Mu'jam al-Mufasshal fi 'Ilmi al-Sharfi, (Beirut: Dar al-Kutub alIlmiyah, 2009)

S. Effendi, Kendjono, Djoko dan Basuki Suhardi, Tata Bahasa Dasar Bahasa Indonesia, (Bandung: Remaja Rosdakarya, 2015), cet. I

Surajiyo, Sugeng Astanto, Sri Andiani, Dasar-dasar Logika, (Jakarta: Bumi Aksara, 2014), cet. VII

Suryadi, Strategi Pembelajaran Pendidikan Karakter, (Bandung: Remaja Rosdakarya, 2013), cet. II

Syaiful Bahri Djamarah dan Aswan Zain, Strategi Belajar Mengajar, (Jakarta: Rineka Cipta, 2006), cet. III

Syaiful Mustofa, Strategi Pembelajaran Bahasa Arab Inovatif, (Malang: UINMALIKI PRESS, 2011)

Wina Sanjaya, Strategi Pembelajaran Berorientasi Standar Proses Pendidikan, (Jakarta: Kencana Prenada Media Group, 2014), cet. XIV 